\title{
Process Nominalizations in Russian ${ }^{*}$
}

\author{
Ilse Zimmermann \\ Potsdam
}

\begin{abstract}
Within a minimalist framework of sound-meaning correlation, the present study concentrates on process nominalizations of Russian. It is shown how these constructions are built up syntactically and semantically and in which respects they differ from other types of nominalizations. The analysis follows a lexicalist conception of word formation and the differentiation of Semantic Form and Conceptual Structure.
\end{abstract}

\section{Introduction}

The present investigation is concerned with process nominalizations of contemporary noncolloquial Russian as in (1)-(2).

(1) vyzdorovlenie pacienta

recovery patient-gen

'the recovery of the patient'

(2) složnyi process usvoenija rebënkom jazyka
complex process acquisition-gen child-instr language-gen
'the complex process of the acquisition of the language by the child'

These expressions refer to processes in a strict sense. It will be shown how these constructions are built up with respect to their internal and external syntax and semantics. The particular questions to be raised are the following:

Which DPs with a deverbal noun as lexical head count as process nominalizations?

What are the characteristics of their containers?

How do process nominalizations differ from other types of nominalizations?

In the following section, I will characterize the theoretical framework of the analysis. Then, the structural properties of Russian nominalizations will be indicated. In section 4, a delimitation of process nominalizations will be aimed at. And in the end, I will summarize.

I restrict the considerations to constructions with a deverbal noun as lexical head which refer to situations (in short: to event nominalizations). Nominalizations referring to participants, circumstances or results are left aside.

\footnotetext{
* The paper refers to work I did on the syntax and semantics of nominalizations in Russian and German (Zimmermann 1967, 1983, 1988, 1991, 1996, to appear). I gained many insights from cooperation with Manfred Bierwisch, Ewald Lang and other researchers in the Arbeitsgruppe Strukturelle Grammatik in Berlin. The linguistic material I will consider stems from my work as a teacher of Russian at the former Pädagogische Hochschule in Potsdam. I collected the examples mainly from scientific texts. I am indepted to Natalja Gagarina for help with the translation of the examples into English. For stimulating discussion, I would like to thank the participants of the workshops on nominalization in the ZAS in Berlin in november 2000 and at the University of Tübingen in april 2001, where I presented parts of this investigation.
} 
Within a minimalist framework of sound-meaning correlation (Chomsky 1995), the analysis follows a lexicalist conception of morphology (Stiebels/Wunderlich 1994, Wunderlich/Fabri 1995, Wunderlich 1997c) and the differentiation of Semantic Form and Conceptual Structure (Bierwisch 1983, 1987, 1997, Bierwisch/Schreuder 1992, Lang 1987, 1990, 1994, Dölling 1997). I assume Phonetic Form, Logical Form and Semantic Form as relevant grammatically determined levels of representation.

The semantic characterization of constituents can be underspecified. It is assumed that the Semantic Form of linguistic expressions involves parameters which are specified in Conceptual Structure (Dölling 1997).

Words as syntactic atoms enter syntactic representations with all affixes of word formation and inflection. With Bierwisch (1989) and Bischof (1991), I assume that nominalizations of verbs - at least in German and in Russian - are derived morphologically and do not constitute products of syntactic rules.

My conception of syntax is very restrictive (Jacobs 1995). For sentences and DPs, I assume the structual layers in (3) and (4), respectively.

\section{(3) CP MoodP TP NegP vP* VP}

\section{(4) DP FP nP* NP}

In the base structure, argument expressions with structural cases of verbs and of the corresponding deverbal nouns are placed in SpecVP, SpecvP or in SpeNP, SpecnP, respectively. The verb raises to Mood or to C (Zimmermann 1999) and - in parallel to sentence structures - the deverbal noun overtly moves to a high functional projection $F$ (Alexiadou 1999, this volume), so that all argument expressions of $\mathrm{N}$ will be to its right (Haider 1992). I will not discuss the nature of the category F. Possibly, it is a further $n$.

The syntactic configurations on the level of LF are the input for semantic interpretation. For functor expressions like verbs and their nominalizations this means that they are combined with their arguments semantically on the basis of LF configurations where chains with traces of moved argument expressions must be taken into consideration. In such derived structures, the head of the chain, the case bearing argument expression $\mathrm{DP}_{i}$, occupies some derived position whereas the tail of the chain $t_{i}$ is in the complement or specifier position of $\mathrm{V}, \mathrm{v}, \mathrm{N}$ or $\mathrm{n}$.

The lexical entries for functor expressions like verbs and their nominalizations include in their argument structure grammatical requirements which must be fulfilled by the respective argument expressions. I call these requirements grammatical argument adresses $\mathrm{G}_{i}$. They are associated with lambda operators $\lambda x_{i}$ which represent the argument positions of the respective functor expression.

The argument positions $\lambda x_{i}$ are ordered from right to left according to the relative depth of embeddedness of the arguments $x_{i}$ in the predicate-argument structure. The highest argument of verbs and event nominalizations constitutes the referential argument (Williams 1981, Bierwisch 1989, Bischof 1991). For mnemotechnic reasons, I will represent it as s (referring to situations). ${ }^{2}$ The other arguments constitute participant, propositional or predicate arguments.

\footnotetext{
'In contrast to this position, see Schoorlemmer (1995) and Alexiadou (1999, this volume).

${ }^{2}$ I assume unsorted variables and do not differentiate between situation types in Semantic Form representations. In contrast see Ehrich/Rapp (2000) and Ehrich (this volume).
} 
(5)

$$
\begin{array}{lll}
\lambda \mathrm{x}_{11} & \cdots & \lambda \mathrm{x}_{\mathrm{i}} \lambda \mathrm{s} \\
\mathrm{G}_{\mathrm{n}} & & \mathrm{G}_{1}
\end{array}
$$

argument structure

with $\mathrm{s} \in \mathrm{e}, \mathrm{x}_{\mathrm{i}} \in\{\mathrm{e}, \mathrm{t},\langle\mathrm{e}, \mathrm{t}\rangle\}$ $\left[\begin{array}{lllllll}\ldots & \mathrm{s} & \ldots & \mathrm{x}_{1} & \ldots & \mathrm{x}_{\mathrm{n}} & \ldots\end{array}\right]$

predicate-argument structure

$\lambda x_{i}$ in (5) represents the argument position of the external argument, $\lambda x_{n}$ is the argument position of the lowest internal argument. For DP arguments, the grammatical features $G_{i}$ are case requirements (Zimmermann 1967) which must be fulfilled by the corresponding DPs as heads in LF chains.

\section{Structural properties of Russian nominalizations}

According to Vendler (1967: 171), nominalizations fall into two categories: imperfect nominals where the verb is still alive and perfect nominals where the verb has become a noun. Harris speaks of half-domesticated and fully domesticated nominalizations.

Russian does not have any imperfect nominals within the spectrum of embedded sentences with a finite verb, infinitival phrases and perfect nominals (Vendler 1967, Koptjevskaja-Tamm 1993). There are no gerunds and no nominalized infinitives. Furthermore, there are no regular perfect nominals comparable to English of-ing gerunds (Abney 1987). One has to learn which verbs allow which nominalizing suffixes, as in German (Bierwisch 1989):

$\begin{array}{llll}\text { (6) pe-nie, otkry-tie, učast-ie, } & \begin{array}{l}\text { razrabot-ka, } \\ \text { working out }\end{array} & \begin{array}{l}\text { proizvod-stvo, } \\ \text { production }\end{array} & \begin{array}{l}\text { prichod, } \\ \text { singing }\end{array}\end{array}$

pobed-a

winning

Russian perfect nominals do not express temporal or modal differentiations. They are unspecified in these respects. To a large extent, this is equally true for aspect.

They do not allow the combination with the reflexive morpheme -sja, in contrast to Polish (cf. formować (sie) / formowanie (sie) 'form / formation').

(7) prizemlenie vertolëta

landing helicopter-gen

'the landing of the helicopter'

Vertolët prizemlilsja.

Helicopter landed

'The helicopter landed.'

Russian perfect nominals do combine with negation (Zimmermann 1988):
nesobljudenie
ukazanij
vrača
non-respecting recommendations-gen
doctor-gen
'the non-respecting of the recommendations of the doctor' 
Modifiers of Russian perfect nominals cannot appear in the adverbial form ending with $\underline{-0}$. The corresponding adjectives agree with the noun in gender, number and case:

$\begin{array}{ll}\text { častoe } \quad \text { opazdyvanie } & \text { Anny } \\ \text { often-agr being late } & \text { Anna-gen } \\ \text { 'Anna's often being late' } & \end{array}$

Anna často opazdyvaet.

Anna often ' is late

'Anna is often late.'

DPs with a deverbal noun as lexical head allow only possessive pronouns or possessive adjectives as prenominal arguments. They, too, agree with the noun.

(10) moë poseščenie muzeja

my-agr visiting museum-gen

'my visiting of the museum'

$\begin{array}{ll}\begin{array}{l}\text { Serëžin neprichod } \\ \text { Serjozha-agr not coming }\end{array} & \begin{array}{l}\text { ko mne } \\ \text { to me }\end{array} \\ \begin{array}{l}\text { Serjozha's not coming to me' } \\ \text { *Serëži neprichod }\end{array} & \text { ko mne } \\ \begin{array}{l}\text { Serjozha-gen not coming } \\ \text { 'Serjozha's not coming to me' }\end{array} & \text { to me }\end{array}$

Except for possessive pronouns and possessive adjectives, all participant arguments occur on the right-hand side of deverbal nouns, with structural or lexical case marking. Arguments marked by the genitive need not be adjacent to the deverbal noun (cf. (2)).

Lexical case and the structural dative are inherited from the corresponding verbs. The lowest structural argument appears in the genitive. The highest structural argument of transitive verbs shows up in the instrumental (Zimmermann to appear).

In (11)-(14), we find some lexical entries for verbs and their nominalizations. I assume with Bierwisch (1989) that nominalizations of verbs referring to situations are formed morphologically - by affixation and - semantically - by the identity function so that verbs and abstract deverbal nouns share the morphological basis and the Semantic Form.

The semantic representation of the lexical entries in (11)-(14) consists of an array of lambda operators, the argument structure, and of a very general indication of the semantic predicate-argument structure of the pertinent verb and its nominalization. Each position for structural arguments is associated with abstract case features \pm hr (there is/is not a higher structural role) and $\pm \mathrm{lr}$ (there is/is not a structural lower role) which predict admissable case forms of the corresponding argument expressions depending on the syntactic category of the governing head. In cases like (11)-(13) all this case information is systematic, redundant and therefore omissible. In contrast, the internal argument of the lexical entries in (14) idiosyncratically shows up in the instrumental. Here one has to do with unsystematic lexical case which must be learnt. 
(11) vyzdorovet'/vyzdorovlenie, vozniknut'/vozniknovenie recover recovery emerge emergence $\lambda x \quad \lambda s \quad[\ldots s \ldots x \ldots]$

$-h r$

$-1 \mathrm{r}$

$\mathrm{V}:$ nom

$\mathrm{N}:$ gen

(12) usvoit'/ usvoenie, znat'/znanie acquire acquisition know knowledge $\lambda y \quad \lambda \mathrm{x} \quad \lambda \mathrm{s} \quad[\ldots \mathrm{s} \ldots \mathrm{x} \ldots \mathrm{y} \ldots]$

$+\mathrm{hr}-\mathrm{hr}$

$-\operatorname{lr} \quad+\mathrm{lr}$

$\mathrm{V}:$ acc nom

$\mathrm{N}$ : gen instr

(13) soobščit'/soobščenie, vručit/ vručenie inform information hand in handing in $\lambda z \quad \lambda y \quad \lambda x \quad \lambda s \quad[\ldots s \ldots x \ldots y \ldots z \ldots]$

$+\mathrm{hr} \quad+\mathrm{hr} \quad-\mathrm{hr}$

-lr + lr + Ir

$\mathrm{V}$ : acc dat nom

$\mathrm{N}$ : gen dat instr

(14) obmenjat'sja/obmen exchange exchange $\lambda y \quad \lambda x \quad \lambda s \quad[\ldots s \ldots x \ldots y \ldots]$

$-\mathrm{hr}$

$-\mathrm{lr}$

$\mathrm{V}$ : instr nom

$\mathrm{N}$ : instr gen

The following noun phrases with deverbal heads illustrate the case realizations of the pertinent argument expressions, in confrontation with infinitival phrases. The examples are given with normal word order. It is important to notice that Russian nominalizations preserve the order of the argument expressions relative to the lexical governor in its base position.

(1) vyzdorovlenie pacienta

recovery patient-gen

'the recovery of the patient'

vyzdorovet'

'recover'

(2) složnyj process usvoenija rebënkom jazyka

complex process acquisition-gen child-instr language-gen

'the complex process of the acquisition of the language by the child'

usvoit' jazyk

acquire language-acc 
(15)

$\begin{array}{llll}\text { nemedlennoe } & \text { soobščenie } & \text { institutami } & \text { firme } \\ \text { immediate-agr } & \text { information } & \text { institutes-instr } & \text { firm-dat }\end{array}$

svoich zakazov

their orders-gen

'the immediate information by the institutes of their orders to the firm'

$\begin{array}{llll}\text { nemedlenno } & \text { soobščit' } & \text { firme } & \text { svoi zakazy } \\ \text { immediately } & \text { inform } & \text { firm-dat } & \text { orders-acc }\end{array}$

(16) obmen tovariščej opytom

exchange comrarades-gen experience-instr

'the exchange of experience by the comrades'

obmenjat'sja opytom

exchange experience-instr

All these structural properties of Russian perfect nominals - except for negation - are independent of the situation type denoted by the deverbal noun. It does not matter whether we have to do with states, activities, accomplishments or achievements. Cf.:

(17) states:

activities:

reading training

accomplishments:

starenie, becoming old

izmenenie, change

vladenie

$$
\begin{array}{ll}
\text { znanie, } & \text { vladenie } \\
\text { knowledge } & \text { mastery }
\end{array}
$$

achievements:

zaberemenenie

becoming pregnant

These differentiations concerning situation types are relevant with respect to the selectional properties of the deverbal nouns. They combine only with certain types of modifiers which are compatible with the respective situation type. And the DPs as a whole occur only in certain container classes, again depending on the DP's reference type.

\section{$4 \quad$ The structure of process nominalizations}

Certain containers and / or the noun process classify situations referred to by nominalizations as processes. The nominalization itself must be compatible with this qualification. 


\subsection{Examples}

(18)

$\begin{array}{llllll}\text { V čëm } & \text { sostoit } & \text { process } & \text { prevraščenija } & \text { truda } \\ \text { in } & \text { what } & \text { consists } & \text { process } & \text { transformation-gen } & \text { labour-gen } \\ \text { V pervuju } & \text { žiznennuju } & \text { potrebnost'? } & \\ \text { into } & \text { first } & \text { living } & \text { necessity } & \end{array}$

'What does the process of transformation of labour into the first living necessity consist of?'

$\begin{array}{llllll}\text { Kakie } & \text { faktory } & \text { sposobstvujut } & \text { etomy } & \text { processu } & \text { i kakie } \\ \text { which } & \text { factors } & \text { promote } & \text { this } & \text { process-dat } & \text { and }\end{array}$

tormozjat ego?

inhibit it-acc

'Which factors promote this process and which ones inhibit it?'

(19) Issleduetsja složnyj process formirovanija is investigated complex process development-gen

\begin{tabular}{|c|}
\hline $\begin{array}{l}\mathrm{V} \\
\text { during }\end{array}$ \\
\hline
\end{tabular}

'The complex process of the development of new intellectuals during the Soviet system is investigated.'

(20) V rabote rassmatrivaetsja process vozniknovenija, in study is considered process emergence-gen

rascveta i upadka ékzistencializma.

flourish-gen and degradation-gen existentialism-gen

'In the study the process of emergence, flourish and degradation of existentialism is considered.'

(21) Vnutri sistemy jazyka vsegda proischodit process within system language-gen always takes place process

$\begin{array}{lllll}\text { pojavlenija } & \text { novych } & \text { èlementov } & \text { i } & \text { otmiranja } \\ \text { emergence-gen } & \text { new } & \text { elements-gen } & \text { and } & \text { dying out-gen }\end{array}$

$\begin{array}{llll}\text { starych, } & \text { process } & \text { zameny } & \text { odnich } \\ \text { old-gen } & \text { process } & \text { substitution-gen } & \text { some-gen }\end{array}$

èlementov drugimi, process peregruppirovki

elements-gen other-instr process reorganization-gen

imejuščichsja elementov i ich pereosmyslenija... 
existing elements-gen and their reinterpretation

'Within the system of language, the processes of emergence of new elements and of dying out of old elements, the process of substitution of some elements by other, the processes of reorganization of existing elements and of their reinterpretation always takes place.'

In (22) and (23) I simply enumerate container expressions and deverbal nouns found in constructions with process nominalizations.

(22) Narrow containers for process nominalizations: ${ }^{3}$ $\begin{array}{lll}\text { ubystrjat', } & \text { zamedljat', } & \text { oblegčat', } \\ \text { escalate } & \text { tormozit', } \\ \text { ease } & \text { inhibit }\end{array}$

sposobstvovat', prepjatstvovat', pomogat'

promote hinder help

proischodit', idti, protekat', načinat'sja, prodolžat'sja,

take place go on run begin continue

končat'sja

finish

prochodit'

go through

ètap, stupen', istorija, temp

stage step history pace

vo vremja, $\quad$ v tečenie

during in the course of

(23) Contained process nouns:

vozniknovenie, pojavlenie, skladyvanie, razvitie,

emergence appearance growing up development

narastanie, perechod, preobrazovanie, izmenenie,

increase transition reorganization change

obogaščenie, nakoplenie, matematizacija

enrichment accumulation mathematization

\footnotetext{
Among the containers as selective hosts for different types of nominalizations Vendler (1967: 131f.) discriminates loose and narrow containers, i.e. contexts of lax or strict hospitality. The latter accept only perfect nominals whereas the former accept perfect as well as imperfect nominals. Cf.:

(i) The collapse of the Germans was gradual.

(ii) *That the Germans collapsed was gradual.

(iii) The collapse of the Germans is likely.

(iv) That the Germans will collapse is likely.
} 


\begin{tabular}{|c|c|c|c|}
\hline $\begin{array}{l}\text { ponimanie, } \\
\text { understanding }\end{array}$ & $\begin{array}{l}\text { poznanie, } \\
\text { cognition }\end{array}$ & $\begin{array}{l}\text { vladenie, } \\
\text { cquisition }\end{array}$ & $\begin{array}{l}\text { obnaruženie, } \\
\text { detection }\end{array}$ \\
\hline $\begin{array}{l}\text { obobščenie, } \\
\text { generalization }\end{array}$ & $\begin{array}{l}\text { izučenie, } \\
\text { investigation }\end{array}$ & $\begin{array}{l}\text { sravnivanie, } \\
\text { comparing }\end{array}$ & $\begin{array}{l}\text { različenie, } \\
\text { differentiation }\end{array}$ \\
\hline \multicolumn{2}{|c|}{$\begin{array}{ll}\text { rešenie, } & \text { proizvodstvo, } \\
\text { decision } & \text { production }\end{array}$} & $\begin{array}{l}\text { erevod, } \\
\text { ransformation }\end{array}$ & \multirow[t]{2}{*}{$\begin{array}{l}\text { zaučivanie, } \\
\text { memorizing }\end{array}$} \\
\hline $\begin{array}{l}\text { proslušivanie, } \\
\text { listening }\end{array}$ & $\begin{array}{l}\text { nazyvanie } \\
\text { naming }\end{array}$ & & \\
\hline $\begin{array}{l}\text { obščenie, } \\
\text { communication }\end{array}$ & $\begin{array}{l}\text { sbliženie, } \\
\text { coming closer }\end{array}$ & $\begin{array}{l}\text { obmen } \\
\text { exchange }\end{array}$ & \\
\hline
\end{tabular}

\subsection{Structural ingredients of process nominalizations}

In the following, two examples will be analysed according to my assumptions on the syntax and semantics of process nominalizations. In (24), we have to do with a copula sentence where the qualification of the nominalization as a process is expressed by a predicative NP. In (25) this characterization is part of a complex term expression.

(24) Vyzdorovlenie pacienta - složnyj process. recovery patient-gen complex process

'The recovery of the patient is a complex process.'

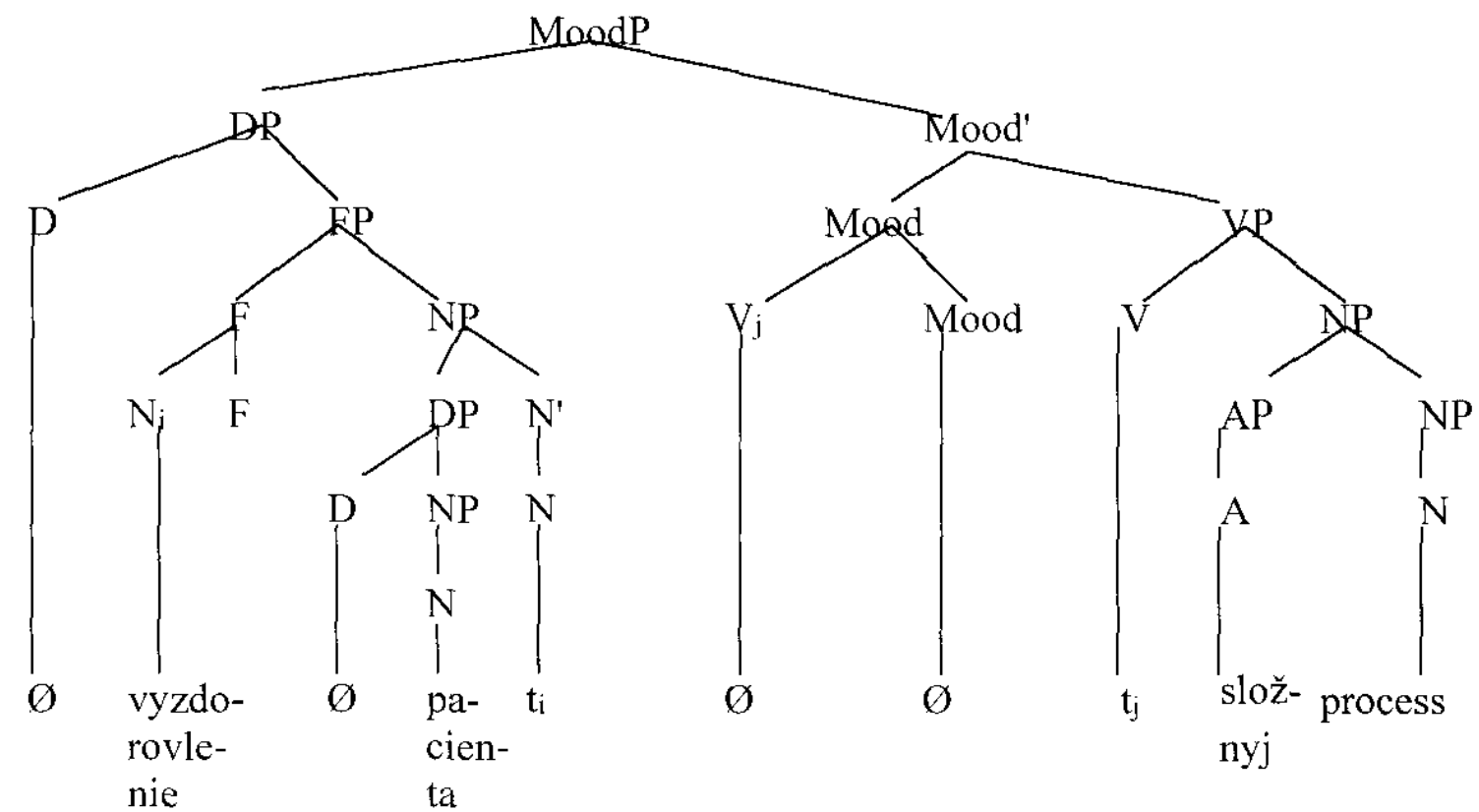

(25) složnyj process vyzdorovlenija pacienta complex process recovery-gen patient-gen

'the complex process of the recovery of the patient' 


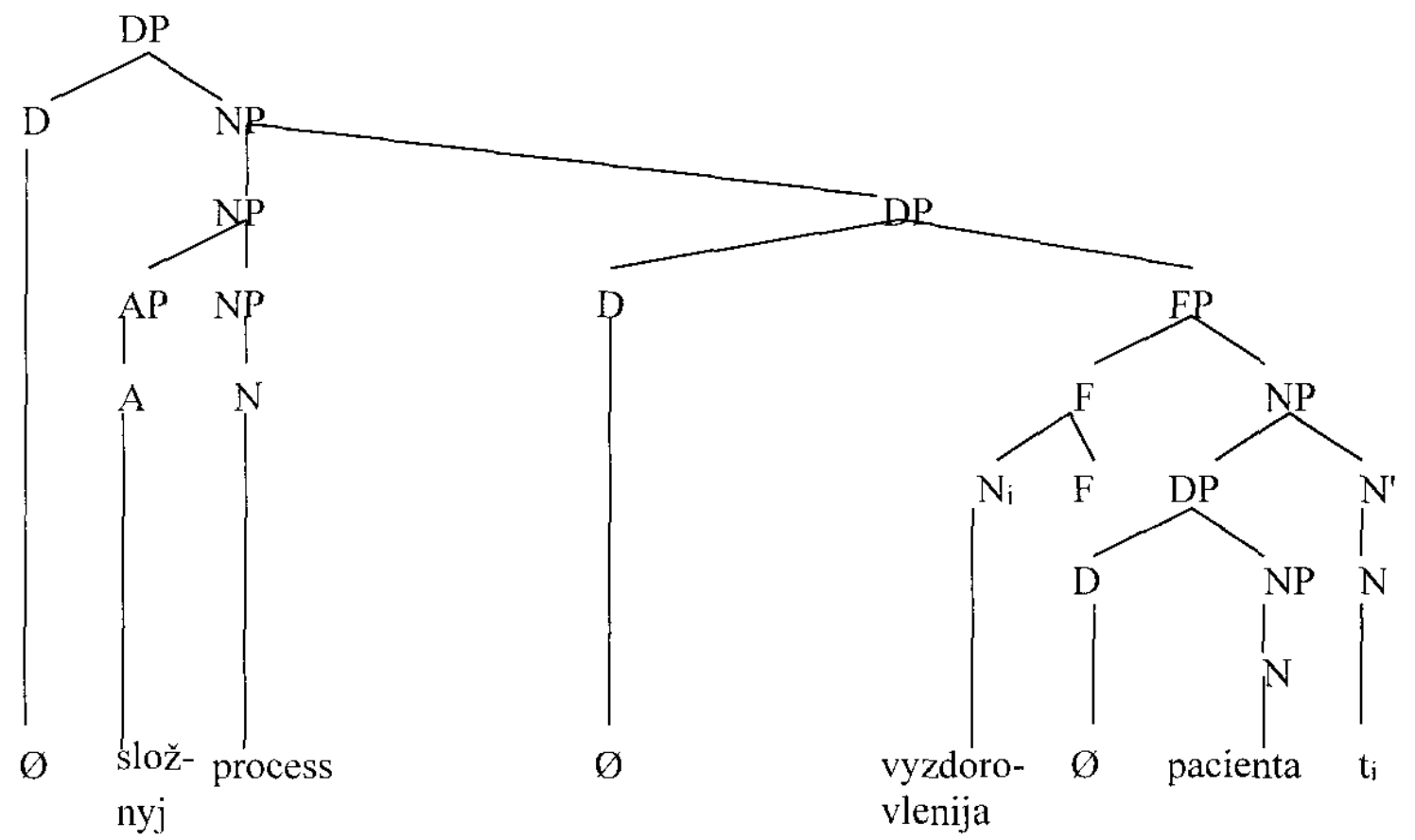

In (24), the layer of TP is ignored. The subject is in the topic position, i.e. in SpecMoodP (cf. Zimmermann 1999). The silent copula - like overt verbs - is adjoined to Mood. The predicative complement of the copula is analysed as NP. Semantically, it is a predicate expression.

In (25), the same NP is combined with a silent determiner. Here we have to do with a term.

In (24) and (25), the deverbal noun vyzdorovlenie has moved to $\mathrm{F}$, and the external argument pacienta is placed in SpecNP, in parallel to the internal argument in the genitivus objectivus of transitive or ditransitive verbs (cf. (2), (15)). In general I assume that structural argument expressions figure in SpecXP whereas lexical argument expressions typically show up in the complement position of the pertinent lexical head.

In (25), there are two adjuncts of the abstract head noun process. Both have modifier function. This is reflected in the semantic representation (see $\left(25^{\prime}\right)$ below).

The following lexical entries including zero morphemes and two shift operations are involved in the structure of (24) and (25):

(26)

/process/

$-\mathrm{V}+\mathrm{N}$

$\lambda s$ [PROCESS s], PROCESS $\in\langle e, t\rangle$

This characterization of the noun process - in a sense - is the heart of my analysis of process nominalizations. I take such linguistic expressions like process 'process', sostojanie 'state' etc. literally, i.e. as elementary expressions classifying situation types. I assume that a system of axioms and definitions is at work at the level of Conceptual Structure which relate such very general qualifications as PROCESS to fine-grained characterizations of activities and accomplishments as proposed in the event calculus by Shanahan (see Hamm / van Lambalgen 2000, this volume), with nine distinguished predicates (hold, happen, initially, initiate, terminate, release, trajectory, clipped, declipped). 
(27)

/vyzdorovlenie/

$-\mathrm{V}+\mathrm{N}$

$\lambda x \lambda s$ [s INST [BECOME [WELL $x]]$ ], INST $\in\langle t,\langle e, t\rangle\rangle$, BECOME $\in\langle t, t\rangle$,

WELL $\in\langle\mathrm{e}, \mathrm{t}\rangle$

In (27), I follow Bierwisch $(1987,1989,1997)$ in assuming that the referential argument of verbs and their nominalizations is introduced by the constant INST which relates propositions to situations.

(28) /pacient/

$-\mathrm{V}+\mathrm{N}$

$\lambda x[$ PATIENT $\mathrm{x}]$, PATIENT $\in\langle\mathrm{e}, \mathrm{t}\rangle$

(29) /složnyj/

$+\mathrm{V}+\mathrm{N}$

$\lambda \mathrm{x}[$ COMPLEX $\mathrm{x}]$, COMPLEX $\in\langle\mathrm{e}, \mathrm{t}\rangle$

(30) $/ \varnothing /$

$+\mathrm{D}+\mathrm{def}$

$\lambda \mathrm{P}$ DEFx $[\mathrm{P} x], \mathrm{DEF} \in\langle\langle\mathrm{e}, \mathrm{t}\rangle, \mathrm{e}\rangle, \mathrm{P} \in\langle\mathrm{e}, \mathrm{t}\rangle$

Russian does not have overt determiners comparable to the German or English definite or indefinite article. I assume corresponding silent ones for Russian.

(31) $/ \varnothing /$

$+\mathrm{V}-\mathrm{N}$

$\lambda \mathrm{P} \lambda \mathrm{x} \lambda \mathrm{s}\left[\mathrm{T} \mathrm{s} \supseteq \mathrm{t}_{\mathrm{o}}\right] \&[\mathrm{~s}$ INST [P $\left.\mathrm{x}]\right], \mathrm{P} \in\langle\mathrm{e}, \mathrm{t}\rangle, \mathrm{T} \in\langle\mathrm{e}, \mathrm{e}\rangle, \supseteq \in\langle\mathrm{e},\langle\mathrm{e}, \mathrm{t}\rangle\rangle$

The silent copula is restricted to present tense and is in complementary distribution with the explicit forms of the copula byt' 'be'.

(32) $/ \varnothing /$

+ Mood

$\lambda \mathrm{P} \exists \mathrm{s}[\mathrm{Ps}], \mathrm{P} \in\langle\mathrm{e}, \mathrm{t}\rangle$

The unmarked semantic function of the functional category Mood consists in existential binding of the referential argument of verbs.

(33) SHIFT gen $_{\text {in }} \lambda y \quad \lambda x\left[x R_{\text {gen }} y\right], R_{\text {gen }} \in\langle e,\langle e, t\rangle\rangle$

gen

I understand constructions like (25) as DPs with an explicative genitival adjunct (cf. Fabricius-Hansen/von Stechow 1989). A shift operation (cf. Zimmmermann 1991, Partee/Borschev 2000) transforms a genitival term into a predicate which can function as a modifier. This shift operation introduces a parameter $\mathrm{R}_{\mathrm{gen}}$ which can be interpreted as identity at the level of Conceptual Structure.

(34) MOD: $\lambda \mathrm{Q} \lambda \mathrm{P} \lambda \mathrm{x}[\mathrm{P} x] \&[\mathrm{Q} x], \mathrm{P}, \mathrm{Q} \in\langle\mathrm{e}, \mathrm{t}\rangle$

The modification template MOD (cf. Zimmermann 1992) serves the unification of two predicates, of the modifier and of the modificandum. In (25), it is applied twice, firstly to the 
combination of složnyj with process and secondly to integrate the explicative genitival phrase vyzdorovlenie pacienta.

With these ingredients we arrive at the Semantic Form of the examples (24)-(25).

(24') $\exists \mathrm{s}\left[\left[\mathrm{T} \mathrm{s} \supseteq \mathrm{t}_{\mathrm{n}}\right] \&\right.$ [s INST [[PROCESS DEFs' [s' INST [BECOME [WELL DEFx [PATIENT $\mathrm{x}]]]]] \&\left[\right.$ [COMPLEX DEFs' $\left[\mathrm{s}^{\prime}\right.$ INST [BECOME [WELL DEFX

[PATIENT $\mathrm{x}]]] 1]]]]]$

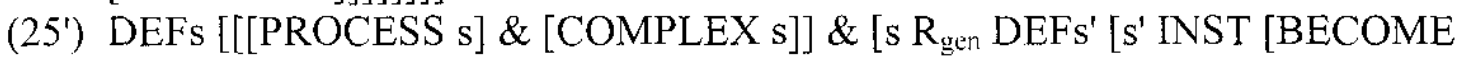

[WELL DEFx [PATIENT x]]]]]]

\subsection{Process nominalizations vs. fact nominalizations}

Let us compare process nominalizations with fact nominalizations (cf. Zimmermann 1983). ${ }^{4}$

$\begin{array}{llll}\text { Točnoe } & \text { sobljudenie } & \text { ukazanij } & \text { vrača } \\ \text { exact-agr } & \text { fulfilment } & \text { recommendations-gen } & \text { doctor-gen }\end{array}$

sposobstvovalo vyzdorovleniju pacienta.

promoted recovery-dat patient-gen

'The exact fulfilment of the recommendations of the doctor promoted the recovery of the patient.'

Here, točnoe sobljudenie ukazanij vrača denotes a fact, whereas vyzdorovlenie pacienta refers to a process.

(36) Fakt točnogo sobljudenija ukazanij vrača

fact exact-agr fulfilment-gen recommendations-gen doctor-gen

sposobstvoval processu vyzdorovlenija pacienta.

promoted process-dat recovery-gen patient-gen

'The fact of the exact fulfilment of the recommendations of the doctor promoted the process of the recovery of the patient.'

Fact nominalizations can be paraphrased by sentences. Process nominalizations do not correspond to complement sentences.

\footnotetext{
4 I assume that the different interpretations of morphologically identical nominals as the collapse of the Germans in (i) and (ii) are due to the respective predicates (Vendler 1967: 123):

(i) The collapse of the Germans was an event.

(ii) The collapse of the Germans is a fact.

Predicates as event, process, action are classifiers of situations (Vendler 1967: 138). Whereas qualifications like event, process, action concern the very nature of the situation we refer to, predicates like fact and their kin characterize assumptions (judgements, presuppositions) about the existence of the described situation in the actual world (Vendler 1967: 143ff.)
} 
(37)

$\begin{array}{lllll}\text { (Tot fakt/ to) čto točno } & \text { sobljudalis' } & \text { ukazanija } & \text { vrača, } \\ \text { that fact that that exactly } & \text { were fulfilled } & \text { recommendations } & \text { doctor-gen }\end{array}$

sposobstvoval(o) vyzdorovleniju pacienta.

promoted recovery-dat patient-gen

'(The fact) that the recommendations of the doctor were exactly fulfilled promoted the recovery of the patient.'

Evidently, the selectional properties of the verb sposobstvovat determine that its external argument must denote a fact while its internal argument refers to a process.

I assume with Dölling (1997) that selectional compatibilities are treated by axioms at the level of Conceptual Structure. Applied to vyzdorovlenie pacienta the respective axioms characterize this entity as compatible with the qualification expressed by process and as acceptable internal argument of sposobstvovat'.

The proposed analysis amounts to saying that process nominalizations are a special type of denotation for situations. Whether the emphasis is on this type or some other aspect of the nominalization involved depends on the selectional properties of the containers. Affirmation, negation, modalization, and questioning are operations which do not occur in process nominalizations. They can be involved in perfect nominalizations, but presuppose special containers.

\subsection{Process nominalizations, aktionsarten and aspect}

Finally, some considerations on the interrelations of process nominalizations, aktionsarten and aspect are in order. Deverbal nouns denoting activities and accomplishments are compatible with the qualification as processes. Sometimes deverbal nouns exhibit a suffix of secondary imperfectivization $(-v a-,-y v a-)$ by which the process character of the denotation is expressed. Cf::

(38)

\begin{tabular}{|c|c|c|c|c|c|c|c|}
\hline $\begin{array}{l}\text { Informacia - } \\
\text { information }\end{array}$ & $\begin{array}{l}\text { eto } \mathrm{o} \\
\text { that } \mathrm{d}\end{array}$ & $\begin{array}{l}\text { načenie } \\
\text { tation }\end{array}$ & $\begin{array}{l}\text { soderža } \\
\text { content }\end{array}$ & & $\begin{array}{l}\text { polučenno } \\
\text { received }\end{array}$ & & $\begin{array}{l}\text { iz } \\
\text { from }\end{array}$ \\
\hline $\begin{array}{l}\text { vnešnego mira } \\
\text { environment }\end{array}$ & $\begin{array}{l}\mathrm{v} \\
\text { during }\end{array}$ & $\begin{array}{l}\text { processe } \\
\text { process }\end{array}$ & $\begin{array}{l}\text { našego } \\
\text { our }\end{array}$ & & $\frac{\text { sposoblenija }}{\text { aptation-gen }}$ & $\begin{array}{l}\mathrm{k} \\
\text { to }\end{array}$ & $\begin{array}{l}\text { nemu } \\
\text { it }\end{array}$ \\
\hline nd $\frac{\text { prisposal }}{\text { adaptatio }}$ & $\frac{\text { vanija }}{\text { gen }}$ & $\begin{array}{l}\mathrm{k} \\
\text { to }\end{array}$ & Ol & & $\begin{array}{l}\text { čuvst. } \\
\text { senses-ger }\end{array}$ & & \\
\hline
\end{tabular}

'Information is the denotation of the content received from the environment during the process of our adaptation to it and of the adaptation of our senses to it.'

Only some pairs of deverbal nouns express this differentiation. In contrast to verbs where the perfect aspect is the marked category, deverbal nouns with an imperfectivizing suffix are marked categories whereas the correspondents to perfect verbs are neutral with respect to the process character of the respective event.
usvoenie
usvaivanie,
sravnenie /
sravnivanie, acquisition
learning
comparison
comparing 


$\begin{array}{llll}\begin{array}{l}\text { nakoplenie / } \\ \text { accumulation }\end{array} & \begin{array}{l}\text { nakaplivanie, } \\ \text { accumulating }\end{array} & \begin{array}{l}\text { poznanie } / \text { poznavanie, } \\ \text { cognition }\end{array} & \text { gaining knowledge } \\ \begin{array}{l}\text { razrabotka } / \\ \text { elaboration }\end{array} & \begin{array}{l}\text { razrabatyvanie } \\ \text { working out }\end{array} & & \end{array}$

\section{$5 \quad$ Open ends}

As is, fortunately, always the case, there remain many interesting open ends.

How do the axioms characterizing the various situation types look like?

What are the exact interrelations of aktionsarten, Russian aspect and process nominalizations? Do we need type/sortal differentiations of events vs. fluents (cf. Hamm/van Lambalgen 2000, this volume)?

Where must we discriminate between event types and event tokens?

Which types of nominalizations put emphasis on a certain subsituation involved in complex situations (cf. Ehrich/Rapp 2000, Ehrich this volume)?

What is wrong or missing in the understanding of abstract deverbal nouns as conversions from verbs to nouns (cf. Bierwisch 1989, Bischof 1991, Stiebels 1997)?

What belongs to the system of axioms at the level of Conceptual Structure and what is given (expressed) in the structure of natural language, in the grammatically determined part of the meaning of a particular construction?

\section{References}

Abney, Steven P. (1987): The English Noun Phrase in its Sentential Aspect. PhD Dissertation, MIT, Cambridge, Mass.

Alexiadou, Artemis (1999): On the Syntax of Nominalization and Possession: Remarks on Parameters of Ergativity. Habilarbeit, Universität Potsdam.

-- (this volume): Word Order Patterns in Greek Nominals: Aspects of Diachronic Change.

Bierwisch, Manfred (1983): Semantische und konzeptuelle Repräsentation lexikalischer Einheiten. In: R. Rủžička, W. Motsch (eds.), 61-99.

-- (1987): Semantik der Graduierung. In: M. Bierwisch, E. Lang (eds.), 91-286.

Bierwisch, Manfred, Schreuder, Robert (1992): From Concepts to Lexical Items. Cognition 42, 23-60.

-- (1989): Event Nominalizations: Proposals and Problems. In: W. Motsch (ed.), 1-73. Überarbeitete Version in: Acta Linguistica Hungarica 40 (1990), 19-84.

-- (1997): Lexical Information from a Minimalist Point of View. In: Ch. Wilder, H.-M. Gärtner, M. Bierwisch (eds.), 227-266.

Bierwisch, Manfred, Lang, Ewald (eds.)(1987): Grammatische und konzeptuelle Aspekte von Dimensionsadjektiven. Berlin: Akademie-Verlag (= Studia grammatica 26/27).

Bischof, Ulrike (1991): Sachverhaltsbezeichnungen des Russischen mit einem Verbalabstraktum als Kern. In: I. Zimmermann (ed.), 69-110.

Chierchia, Gennaro (1982): Nominalization and Montague Grammar: A Semantics without Types for Natural Languages. Linguistics and Philosophy 5. 3, 303-354.

Chomsky, Noam (1995): The Minimalist Program. Cambridge, Massachusetts, London, England: MIT Press (= Current Studies in Linguistics Series 28).

Doherty, Monika (ed.)(1999): Sprachspezifische Aspekte der Informationsverteilung. Berlin: Akademie Verlag (= Studia grammatica 47 )

Dölling, Johannes (1997): Semantic Form and Abductive Fixation of Parameters. In: R. van der Sandt, R. Blutner, M. Bierwisch (eds.), 113-139.

Ehrich, Veronika (this volume): The Thematic Interpretation of Plural Nominalizations.

Ehrich, Veronika, Rapp, Irene (2000): Sortale Bedeutung und Argumentstruktur: ung-Nominalisierungen im Deutschen. In: Zeitschrift für Sprachwissenschaft 19. 2, 245-303.

Fabb, Nigel A. J. (1984): Syntactic Affixation. PhD Dissertation, MIT, Cambridge, Mass. 
Fabricius-Hansen, Cathrine, von Stechow, Arnim (1989): Explikative und implikative Nominalerweiterungen im Deutschen. Zeitschrift für Sprachwissenschaft 8. 2, 173-205.

Fabricius-Hansen, Cathrine, Lang, Ewald, Maienborn, Claudia (eds.)(2000): Approaching the Grammar of Adjuncts. Proceedings of the Oslo Conference, September 22-25, 1999. Als: ZAS Papers in Linguistics 17.

Grimshaw, Jane (1990): Argument Structure. Cambridge, Mass.: MIT Press.

Groenendijk, Jeroen, de Jongh, Dick, Stockhof, Martin (eds.)(1987): Studies in Discourse Representation Theory and the Theory of Generalized Quantifiers. Dordrecht, Holland, Providence, U.S.A: Foris (= GroningenAmsterdam Studies in Linguistics (GRASS) 8).

Haider, Hubert (1992): Branching and Discharge. In: Arbeitspapiere des Sonderforschungsbereichs 340, Nr.23. Universitäten Stuttgart und Tübingen, 1-31.

Hamm, Fritz, van Lambalgen, Michiel (2000): Event Calculus, Nominalisation, and the Progressive. Manuskript.

-- (this volume): Formal Foundations for Semantic Theories of Nominalisation.

Jackendoff, Ray S. (1975): Morphological and Semantic Regularities in the Lexicon, Language 51. 3, 639-671.

Jacobs, Joachim (1995): Wieviel Syntax braucht die Semantik? Möglichkeiten und Grenzen einer sparsamen Theorie der Bedeutungskomposition. Theorie des Lexikons. Arbeiten des Sonderforschungsbereichs 282, $\mathrm{Nr}$. 73. Düsseldorf: Heinrich-Heine-Universität.

Koptjevskaja-Tamm, Maria (1993): Nominalizations. London: Routledge.

Lang, Ewald (1987): Semantik der Dimensionsauszeichnung räumlicher Objekte. In: M. Bierwisch, E. Lang (eds.), 287-458.

-- (1990): Sprachkenntnis, Objektwissen und räumliches Schließen. Zeitschrift für Literaturwissenschaft und Linguistik 78, 59-97.

-- (1994): Semantische und konzeptuelle Struktur: Unterscheidung und Überschneidung. In: M. Schwarz (ed.), $25-40$.

Motsch, Wolfgang (ed.)(1989): Wortstruktur und Satzstruktur. Berlin (= LS/ZISW/A 194).

Partee, Barbara (1987): Noun Phrase Interpretation and Type Shifting Principles. In: J. Groenendijk, D. de Jongh, M. Stockhof (eds.), 115-143.

Partee, Barbara H., Borschev, Vladimir (2000): Genitives, Relational Nouns, and the Argument-Modifier Distinction. In: C. Fabricius-Hansen, E. Lang, C. Maienborn (eds.), 177-201.

Rozwadowska, Bożena (1997): Towards a Unified Theory of Nominalizations. External and Internal Eventualities. Wrocław: Wydawnictvo Universytetu Wrocławskiego.

Růžička, Rudolf, Motsch, Wolfgang (eds.)(1983): Untersuchungen zur Semantik. Berlin: Akadmie-Verlag (= Studia grammatica 22).

van der Sandt, Rob, Blutner, Reinhard, Bierwisch, Manfred (eds.) (1997): From Underspecification to Interpretation. Working Papers of the Institute of Logic and Linguistics. Heidelberg: IBM.

Schoorlemmer, Maaike (1995): Participial Passive and Aspect in Russian. Utrecht: LEd (OTS Dissertation Series).

Schwarz, Monika (ed.)(1994): Kognitive Semantik: Ergebnisse, Probleme, Perspektiven. Tübingen: Narr. (= Tübinger Beiträge zur Linguistik 395).

Stiebels, Barbara (1997): Noun-Verb Symmetries in Nahuatl Nominalizations. Theorie des Lexikons. Arbeiten des Sonderforschungsbereichs 282, Nr. 98. Düsseldorf: Heinrich-Heine-Universität. Überarbeitete Version in: Natural Language and Linguistic Theory 17 (1999), 783-836.

Stiebels, Barbara, Wunderlich, Dieter (1994): Morphology Feeds Syntax: The Case of Particle Verbs. Linguistics 32, 913-968.

Tappe, Hans Thilo, Löbel, Elisabeth (eds.)(1996): Die Struktur der Nominalphrase. Wuppertaler Arbeitspapiere zur Sprachwissenschaft (WAS), Nr.12.

Vendler, Zeno (1967): Linguistics in Philosophy. Ithaca, London: Cornell University Press.

Wilder, Chris, Gärtner, Hans-Martin, Bierwisch, Manfred (eds.)(1997): The Role of Economy Principles in Linguistic Theory. Berlin: Akademie Verlag (= Studia grammatica 40).

Williams, Edwin (1981): Argument Structure and Morphology. The Linguistic Review 1. 1, $81-114$.

Wunderlich, Dieter (1997a): CAUSE and the Structure of Verbs. Linguistic Inquiry 28. 1, 27-68.

-- (1997b): Argument Extension by Lexical Adjunction. Journal of Semantics 14, 95-142.

-- (1997c): The Minimalist Model of Inflectional Morphology. In: Ch. Wilder, H.-M. Gärtner, M. Bierwisch (eds.), 267-298.

Wunderlich Dieter, Fabri, Ray (1995): Minimalist morphology: An Approach to Inflection. Zeitschrift für Sprachwissenschaft 14. 2, 236-294.

Zimmermann, Ilse (1967): Der Parallelismus verbaler und substantivischer Konstruktionen in der russischen Sprache der Gegenwart. Zeitschrift für Slawistik 12. 5, 744-755.

-- (1983): Untersuchungen zum Verhältnis von Substantivgruppe und Nebensatz. In: R. Růžička, W. Motsch (eds.), 201- 242.

-- (1988): Nominalisierungen mit dem Präfix ne im Russischen. Zeitschrift für Phonetik, Sprachwissenschaft und Kommunikationsforschung 41. 1, 23-30.

-. (1991): The "Subject" in Noun Phrases. In: I. Zimmermann (ed.), 33-68. 
-- (1992): Der Skopus von Modifikatoren. In: I. Zimmermann, A. Strigin (eds.), 251-279.

-- (1996): Substantivgruppen mit einem Adjektivabstraktum als Kern. In: H. Th. Tappe, E. Löbel (eds.), 189208.

-- (1999): Die Integration topikalischer DPs in die syntaktische Struktur von Sätzen. In: M. Doherty (ed.), 41-60.

-- (to appear): The Categorial Dependence of Structural Cases in Russian. In: Proceedings of FDSL IV, University of Potsdam, November 2001.

Limmermann, Ilse (ed.)(1991): Syntax und Semantik der Substantivgruppe. Berlin: Akademie Verlag (= Studia grammatica 33 ).

Zimmermann, Ilse, Strigin, Anatoli (eds.)(1992): Fügungspotenzen. Zum 60. Geburtstag von Manfred Bierwisch. Berlin: Akademie Verlag (= Studia grammatica 34). 